The Disposition of Nature 



\section{The Disposition of Nature}

Environmental Crisis And

\section{WORLD Literature}

JenNifer WENZEL

F O R D H M U N I VERS ITY P RES S

New York 2020 
Fordham University Press gratefully acknowledges financial assistance and support provided for the publication of this book by Columbia University.

Copyright (C) 2020 Fordham University Press

All rights reserved. No part of this publication may be reproduced, stored in a retrieval system, or transmitted in any form or by any means-electronic, mechanical, photocopy, recording, or any other-except for brief quotations in printed reviews, without the prior permission of the publisher.

Fordham University Press has no responsibility for the persistence or accuracy of URLs for external or thirdparty Internet websites referred to in this publication and does not guarantee that any content on such websites is, or will remain, accurate or appropriate.

Fordham University Press also publishes its books in a variety of electronic formats. Some content that appears in print may not be available in electronic books.

Visit us online at www.fordhampress.com.

Library of Congress Cataloging-in-Publication Data available online at http://catalog.loc.gov.

Printed in the United States of America

First edition 
in memory of Barbara Harlow 
